\title{
Aktuální stav problematiky ochranných pásem vodních zdrojů
}

\section{ROBERT KOŘÍNEK, HANA NOVÁKOVÁ, JAROSLAVA NIETSCHEOVÁ}

\author{
Klíčová slova: ochranné pásmo - vodní zdroj - povrchová voda - podzemní voda - legislativa - vodní zákon
}

\section{SOUHRN}

Aktuální situace v oblasti ochranných pásem vodních zdrojů (dále také OPVZ) je $\vee$ České republice dlouhodobě problematická, a to nejen z hlediska jejich vymezování, ale také správného nastavení opatření či dostupnosti dat veřejnosti. Ochranná pásma jsou v České republice vymezována již více než 50 let, přičemž mnohá z nich jsou stále v platnosti, a to i přes objektivní důvody ke změně.

Z hlediska legislativních nástrojů se vymezování OPVZ pohybuje v nesourodém prostředí. Jednak zde platí vyhláška č. 137/1999 Sb., kterou se stanoví seznam vodárenských nádrží a zásady pro stanovení a změny ochranných pásem vodních zdrojů [1], jednak se vymezování OPVZ rídí zejména § 30 zákona č. 254/2001 Sb., o vodách a o změně některých předpisů (vodní zákon) ve znění pozdějších predpisů [2]. Tím mohou vznikat odlišné postoje k celé problematice.

\section{ÚVOD}

Historický vývoj vymezování OPVZ na našem území je z hlediska pochopení aktuální situace zásadní. Prístupy k ochranným pásmům se v minulosti lišily a je dnes obtížné nahližet na všechna OPVZ jednotně.

Pokud je řeč o vodním zdroji, který má speciální ochranu stanovenou před rokem 1955, dá se očekávat, že v příslušném dokumentu správního úřadu bude uvedeno území, na kterých platí určité zásady a podmínky. V tomto prípadě nebude ž̌ejmě ještě použit pojem "ochranné pásmo vodního zdroje”, každopádně však toto opatření bylo v té době platné a pro dotčené subjekty závazné.

S účinností zákona č. 11/1955 Sb., o vodním hospodářství stanovoval vodohospodářský orgán po provedeném rrízení již ochranná území. Ochrana vodních zdrojů se stala záležitostí nejen vodohospodářu, ale také hygienických orgánů. $\checkmark$ této souvislosti byly vydány směrnice Ministerstva zdravotnictví a Ústřední správy vodního hospodářství č. 14/1954 Sb., Hygienické předpisy pro stanovení pásem hygienické ochrany kolem zdrojů určených k hromadnému zásobování pitnou a užitkovou vodou.

K další změně došlo vydáním zákona č. 20/1966 Sb., o péči o zdraví lidu. Zde bylo k určitým úkonům, mj. i k vymezení pásem hygienické ochrany (dále také $\mathrm{PHO}$ ), zapotřebí závazného posudku orgánu hygienické služby. Jak vyplývá z názvu typu vymezení - pásma - jednalo se o ochranu plošnou, zpravidla $\checkmark$ celém povodí jednotlivých vodních zdrojů.

Výše uvedené předpisy vzniklé po roce 1955 Ize považovat za počátky koncepce speciální ochrany vodních zdrojů.

Dalším zásadním krokem bylo vydání zákona č. 138/1973 Sb., o vodách a směrnice Ministerstva zdravotnictví a hlavního hygienika ČSR č. 51/1979 o hlavních hygienických zásadách pro stanovení vymezení a využivání ochranných pásem vodních zdrojů určených k hromadnému zásobování pitnou a užitkovou vodou a pro zřizování vodárenských nádrží. Ta byla registrována v části 20/1979 Sbírky zákonů jako obecně závazný předpis. Právě v době platnosti těchto dokumentů bylo na území České (resp. Československé) republiky jednotnou metodikou navrženo několik set pásem hygienické ochrany vodních zdrojů povrchových a podzemních vod. Jednotný byl v podstatě také soubor zákazů a omezujících činností vztahujících se na území stanovených ochranných pásem. Principiálně bylo kolem každého jímacího objektu vymezeno pásmo hygienické ochrany 1. stupně a dále dvě části pásma hygienické ochrany 2. stupně - vnitřní a vnější. U vnitřní části byla většinou vypočítána nebo odhadnuta doba 50 denního zdržení vody v horninovém prostředí, u vnější části pak bylo počíáno s infiltračním povodím daného vodního zdroje. Celá řada takto správním rozhodnutím vodohospodářských orgánů stanovených pásem je v platnosti do dnešní doby, protože tato správní rozhodnutí nebyla později zrušena ani nebyla časově omezena.

Pásma stanovená těmito postupy vycházela z poměrně nepřesných dat, resp. určité nejistoty přirozeně vyplývaly z reálného nedostatku potřebných údajů. V celé řadě prípadů se jedná o pásma př́liš rozsáhlá či centricky stanovená, která mnohdy ani nerespektovala směr prítoku vody k jímacímu území. Rovněž tento př́stup často nerespektoval místní specifické hydrogeologické systémy.

K první změně v rámci samostatné České republiky došlo po vydání zákona č. 14/1998 Sb. (tzv. Malá novela vodního zákona), resp. vyhlášky MžP č. 137/1999 Sb., kterou se stanoví seznam vodárenských nádrží a zásady pro stanovení a změny ochranných pásem vodních zdrojů a která současně zrušila směrnici č. 51/1979. Zásadní změnou byla redukce ochranných pásem pouze na dva stupně a dále vznik institutu individuálního posouzení jak rozsahu ochranných pásem, tak návrhů limitujících činnostís tím, že budou odvozeny především od analýzy rizika ohrožení vydatnosti, jakosti nebo zdravotní nezávadnosti vodního zdroje [3].

V současné době se OPVZ podle ustanovení § 30 vodního zákona (tzv. Velká novela vodního zákona) stanovují za účelem ochrany vydatnosti, jakosti a zdravotní nezávadnosti vodního zdroje využívaného nebo využitelného jen pro zásobování pitnou vodou. Uvedený způsob ochrany vodních zdrojů je tzv. speciální ochranou vodních zdrojů, která je zcela individuálně stanovena vždy pro konkrétní území individuálním správním aktem příslušného vodoprávního úrăadu, tj. jeho správním rozhodnutím, podle zákona č. 500/2004 Sb., správní rád, resp. opatřením obecné povahy po novele vodního zákona zákonem č. 150/2010 Sb. [4, 5].

Podle $\S 30$ odst. 13 vodního zákona č. 254/2001 Sb. Ministerstvo životního prostředí ČR zmocnění vyhláškou stanoví seznam vodárenských nádrží a zásady pro stanovení a změny ochranných pásem vodních zdrojů. Tato vyhláška však od doby vzniku současného vodního zákona (za 15 let jeho platnosti) nebyla príijata, takže i nadále platí s vodním zákonem ne zcela kompatibilní vyhláška původní č. 137/1999 Sb. 


\section{METODIKA, PODKLADY}

Návrh aktualizace legislativních nástrojů a metodických postupů pro stanovení ochranných pásem vodních zdrojů byl zpracován v roce 2016 v rámci projektu Podpora výkonu státní správy v oblasti voda, část Odborná podpora legislativních předpisů v rámci vodního hospodářství, jehož zadavatelem bylo Ministerstvo životního prostředí ČR a zpracovatelem Výzkumný ústav vodohospodářský T. G. Masaryka, veřejná výzkumná instituce.

Metodicky bylo nutno vycházet z relevantních aktuálně platných právních předpisů a dále z metodických dokumentů a doporučení, přestože tyto nebyly doposud uvedeny v platnost. Hlavní obecně závazné právní předpisy jsou:

— zákon č. 254/2001 Sb., o vodách a o změně některých zákonů (vodní zákon), ve znění pozdějších předpisů,

— vyhláška MŽP č. 137/1999 Sb., kterou se stanoví seznam vodárenských nádrží a zásady pro stanovení a změny ochranných pásem vodních zdrojů.

Mezi další relevantní právní předpisy patři:

— vyhláška č. 501/2006 Sb., o obecných požadavcích na využívání území,

— vyhláška č. 26/2007 Sb., kterou se provádí zákon č. 265/1992 Sb., o zápisech vlastnických a jiných věcných práv $\mathrm{k}$ nemovitostem, ve znění pozdějších predpisů, a zákon č. 344/1992 Sb., o katastru nemovitostí České republiky (katastrální zákon), ve znění pozdějších předpisů, (katastrální vyhláška),

— zákon č. 334/1992 Sb., o ochraně zemědělského půdního fondu,

— zákon č. 289/1995 Sb., o lesích,

— vyhláška č. 268/2009 Sb., o technických požadavcích na stavby,

— vyhláška č. 590/2002 Sb., o technických požadavcích na vodní díla,

— zákon č. 139/2002 Sb., o pozemkových úpravách,

— zákon č. 326/2004 Sb., o rostlinolékařské péči a o změně některých souvisejících zákonů.

Problematickou oblastí prí tvorbě OPVZ je také doposud nerealizované sjednocení postupů pro stanovování a změny ochranných pásem. Poslední verze připravovaných dokumentů, které byly zpracovateli poskytnuty, pochází z roku 2012:

- Tvorba metodik pro vymezování ochranných pásem vodních zdrojů, závěrečná zpráva, Výzkumný ústav meliorací a ochrany půdy, v. v. i., Praha, únor 2012,

- Metodika pro zpracování dokumentace ochranných pásem povrchových vodních zdrojů, Výzkumný ústav meliorací a ochrany půdy, v. v. i., Povodí Vltavy, státní podnik, Praha, únor 2012,

- Katalog opatření OPVZ, Výzkumný ústav meliorací a ochrany půdy, v. v. i., Povodí VItavy, státní podnik, Praha, únor 2012,

- Ideový návrh směrnice pro stanovení ochranných pásem vodních zdrojů podzemní vody, Výzkumný ústav meliorací a ochrany půdy, v. v. i., Povodí VItavy, státní podnik, Praha, únor 2012,

- Metodické doporučení k § 2, odstavec 3 a 4, vyhlášky č. 137/1999 Sb. po její navrhované změně, Výzkumný ústav meliorací a ochrany půdy, v. v. i., Povodi Vltavy, státní podnik, Praha, únor 2012 [6].

$\checkmark$ rámci úkolu Aktualizace ochranných pásem vodních zdrojů řešeného rovněž v rámci projektu Podpora výkonu státní správy v oblasti voda je dlouhodobě prováděna aktualizace a ověření správnosti geoprostorových a dokumentačních dat ochranných pásem vodních zdrojů a vodárenských nádrži z podkladů získaných od krajských vodoprávních úradů a vodoprávních úřadů obcí s rozšířenou působností, popř. od správců povodí nebo uživatelů vodních zdrojů. Jedná se o tyto typy podkladů:

- geoprostorová data OPVZ v některém z běžně použivaných datových formátů pro GIS nebo CAD (ESRI shapefile, ESRI personal nebo file geodatabase, $. d w g, . d x f, . d g n)$, ideálně s polygonovou geometrií a připojenými atributními informacemi,
- skenované dokumenty (vodoprávní rozhodnutí, mapové podklady) vztahující se kjednotlivým OPVZ,

- papírové dokumenty zaslané na adresu VúV TGM.

Podnětem pro změnu stávajících dat jsou také podněty od Ministerstva životního prostředí, Ministerstva zemědělství, Ústředního kontrolního a zkušebního ústavu zemědělského, zemědělských družstev, popř. dalších subjektů, které naleznou chyby ve vymezení ochranných pásem.

Zásadním zdrojem informací v rámci řešení projektu byly realizační a provozní zkušenosti státních podniků povodí a subjektů z oblasti provozu vodohospodářských infrastruktur.

\section{VÝSLEDKY A JEJICH DISKUSE}

Aktuální situaci v oblasti ochranných pásem vodních zdrojů Ize definovat třemi základními problematickými okruhy:

- neaktualizované legislativní prostředí,

- absence oficiálních metodických nástrojů a postupů pro stanovení, změny a zrušení ochranných pásem vodních zdrojů pro povrchové a podzemní vody,

— absence aktuální a rádně vedené jednotné evidence OPVZ v rámci ČR.

V návaznosti je pak zapotřebí věnovat prostor k analýzám následujících otázek:

- potřebě zavedení všech OPVZ (včetně PHO) do katastru nemovitostí,

- aktualizace a sjednocení postupů pro náhrady za omezení uživání nemovitostí a prováděných činností v OPVZ,

— stanovení potřeby a povinnosti pro prípadné přehodnocování OPVZ (včetně $\mathrm{PHO}$ ) podle vývoje jakosti, vydatnosti nebo zdravotní nezávadnosti vodního zdroje nebo místních podmínek.

\section{Základní teze}

Aby bylo při řešení problému dosaženo jednotného a koordinovaného př́stupu, je nutno stanovit základní teze a vytyčit si cíle, na které je bezpodmínečně nutné se zaměřit. Ochrana vodních zdrojů by proto měla být vnímána jako zcela zásadní společenský problém a nezbytná potřeba. Jejich ochranu je nutno jednoznačně vnímat jako veřejný zájem nadřazený všem jiným zájmům v území včetně zemědělského obhospodařování pozemků tak, jak je to již stanoveno vodním zákonem ( $\$ 30$ odst. 1).

Vzhledem $k$ existujícím podmínkám v řadě ochranných pásem I. stupně (např. mosty dálnice D1 vedoucí přes vodárenskou nádrž Švihov, obr. 1) je třeba zvážit nutnost úplného uzavření ochranného pásma I. stupně zákazem vstupu pro kohokoliv mimo odběratele vody z vodního zdroje nebo subjektu s právem hospodařit s vodárenskou nádrží. Je třeba vzít v úvahu, že v těchto územích budou i jiní vlastníci nemovitostí, než je odběratel vody nebo stát, a zákazem vstupu a vjezdu do ochranného pásma I. stupně je jen nepřiměřeně zasahováno do jejich vlastnických práv. Na tom nic nemění ani fakt, že stanoveným úředním postupem Ize pro vlastníky nemovitostí získat prístup $k$ jejich majetku - §30 odst. 7 vodního zákona. Tento postup je zbytečně administrativně náročný. 


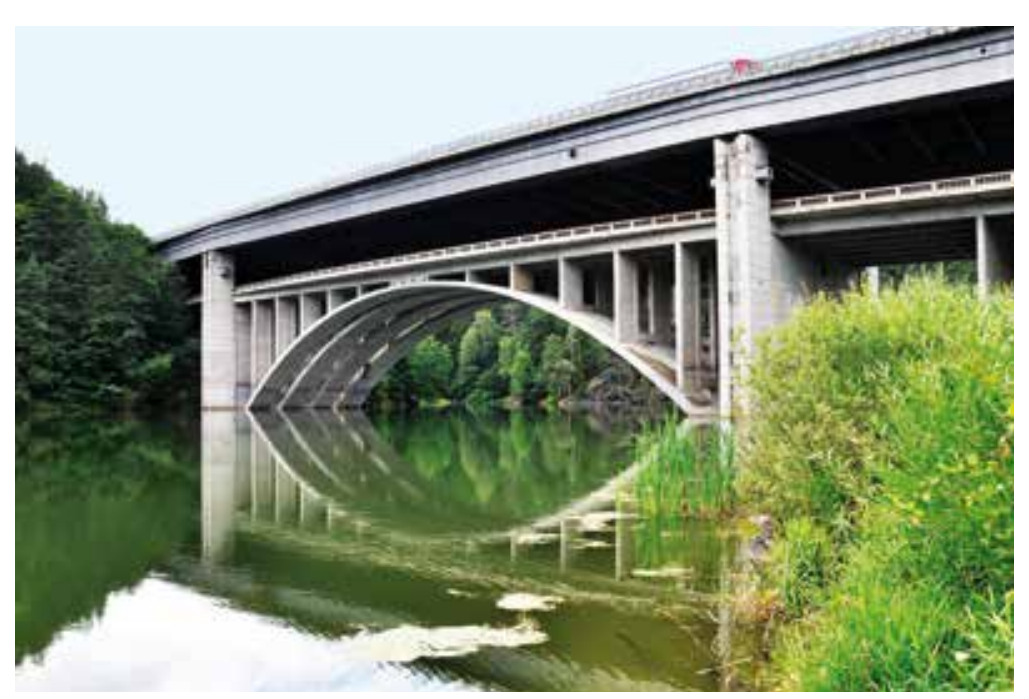

Obr. 1. Silniční most dálnice D1 překračující vodárenskou nádrž Švihov u obce Pišṫ (2016) Fig. 1. Road bridge of D1 highway crossing a water supply reservoir Švihov near the village Píst' (2016)

Vodním zákonem je jasně stanoveno, že "stará" ochranná pásma (například PHO - pásma hygienické ochrany) se považují co do rozsahu za ochranná pásma stanovená opatřením obecné povahy (přechodné ustanovení zákona č. 150/2010 Sb., kterým se mění zákon č. 254/2001 Sb.). Velmi problematické se však toto ustanovení jeví v tom, že vyžaduje, aby každá případná změna existujícího OPVZ byla provedena tak, že se celé OPVZ stanoví znovu opatřením obecné povahy. To velmi komplikuje situaci při nutných změnách existujících OPVZ, zvláště jsou-li velmi rozsáhlá. Fakticky lze vidět silné tendence toto ustanovení nerespektovat z logických a praktických důvodů. Potřeba zvážit tento princip je tedy velmi silná a musí být řešena při nejbližší novele vodního zákona.

Ochrana nemovitosti zapsané v katastru nemovitostí by měla být vždy na celou parcelu (parcelní číslo) i v případě, že hranice ochranného pásma probíhá mimo hranice jednotlivých parcel. Tato skutečnost odpovídá současným možnostem evidence katastru nemovitostí a potřebě navrhovatelů OPVZ.

Rozhodnutím Ministerstva zemědělství ze dne 19. 5. 1998 bylo uloženo tehdejším akciovým společnostem Povodí zajistit postupy pro poskytování náhrad za omezení užívání nemovitostí v ochranných pásmech vodárenských nádrží ve vlastnictví subjektů Povodí podle Metodického pokynu k uplatňování náhrad za omezení uživání nemovitostí v ochranných pásmech vodárenských nádrží podle § 19 odst. 5 a 6 zákona č. 138/1973 Sb., o vodách, ve znění zákona č. 14/1998 Sb. Poskytování náhrad bylo uloženo realizovat na základě písemných žádostí vlastníků pozemků, popř. nájemců pozemků (na základě plné moci od vlastníků pozemků), a následně písemně uzavřených smluv. Poté vydalo MZe Metodický pokyn k postupu státních podniků Povodí při poskytování náhrad za omezení užívání nemovitostí v ochranných pásmech vodních zdrojů podle $\S 30$ odst. 11 zákona č. 254/2001 Sb. Pokyn v článku 2 připustil možnost dohody mezi podnikem Povodía vlastníkem, popř. uživatelem, bude-li k tomu zmocněn vlastníkem, o paušální náhradě, nebude-li hrazeno prokázané omezení užívání nemovitostí. Zároveň tento metodický pokyn stanovil v článku 4, že postup při uplatňování a vyplácení náhrady za omezení užívání nemovitostí se řídí metodickým pokynem z roku 1998 až do doby, kdy budou všechna ochranná pásma vodárenských nádrží stanovena nově podle platného vodního zákona.

Je zřejmé, že paušální náhrady stanovené před dvaceti lety již neodpovídají současnosti, a bylo by je třeba i několikanásobně zvýšit tak, aby byly uspokojeny oprávněné nároky vlastníků, popř. uživatelů pozemků. Zároveň je vhodné v odborné diskusi probrat i otázku možných kompenzací pro vlastníky a uživatele pozemků za dobrovolné a vhodné hospodaření v ochranných pásmech bez použití prostředků na ochranu rostlin - např. zatravnění pozemků.
Některá ochranná pásma vodních zdrojů, stanovená poměrně dávno v minulosti, jsou oficiálně stále platná a musí být respektována, pokud nebudou zrušena. Proto je třeba zvážit možnost stanovení „zániku ochranných pásem vodních zdrojü“, popř. povinnosti jejich prè-vymezení, nebudou-li v nějakém termínu stanoveném zákonem zaevidována v katastru nemovitostí.

\section{Úpravy a změny legislativního prostředí ve vazbě na OPVZ}

Novelizace a změny legislativních nástrojů s cílem sjednotit postupy při vymezování, změnách a rušení OPVZ jsou v současné situaci stěžejní záležitostí. Úpravy je nutno provést $v$ platném vodním zákoně a $v$ dalších relevantních právních předpisech a zároveň je třeba vydat novou prováděcí vyhlášku, která naplní zákonné zmocnění a nahradí zastaralou vyhlášku č. 137/1999 Sb. Diskuse kolem řešení problematiky probíhají již řadu let, realizace se však stále odkládá. Vzhledem k omezenému rozsahu př́spěvku je $v$ následující části věnována pozornost pouze vodnímu zákonu a vyhlášce č. 137/1999 Sb.

\section{Vybrané návrhy novely vodního zákona}

\section{$\S 20$ ODST. 3}

Na základě změny vyhlašování ochranných pásem vodních zdrojů formou opatření obecné povahy je zapotřebí upravit slovní formulaci v následujícím odstavci. Místo slova rozhodnutí se užije slovní spojení opatření obecné povahy.

„Vodoprávní úrad je povinen zaslat príslušnému katastrálnímu úřadu údaje potřebné k evidenci ochrany území podle odstavce 2 do 30 dnů ode dne nabytí účinnosti opatření obecné povahy, kterým byla tato ochrana území vymezena."

$\checkmark$ této souvislosti se rovněž diskutuje varianta, kdy by výše uvedená povinnost, kontaktovat katastrální úrad a evidovat stanovené ochranné pásmo v katastru nemovitostí, byla přesunuta na ten subjekt, který podal návrh na stanovení ochranného pásma.

\section{$\S 30$ ODST. 5}

Na konci textu se doplní věta: „Ochrannépásmo ll. stupně se nestanovív prípadech, kdy obecná ochrana vod a stanovení území ochranného pásma l. stupně v daných mistnich podmínkách dostatečně zajištuji ochranu vydatnosti, jakosti a zdravotní nezávadnosti vodního zdroje."

Tento požadavek byl původně ve vyhlášce č. 137/1999 Sb. Znění povinnosti je dostačující, mělo by ale být prímo součástí zákona a odpovídajícího odstavce.

\section{ZÁKAZ VSTUPU A VJEZDU DO OPVZ I. STUPNĚ - § 30 ODST. 7}

Stanovená ochranná pásma vodních zdrojů jsou v některých prípadech velmi rozsáhlá a v řadě případů jsou situována v zastavěném území nebo území silně zemědělsky obhospodařovaném. Je proto prakticky nemožné, aby zákazy vstupu a vjezdu do ochranných pásem I. stupně byly skutečně dodržovány. Kromě toho povolování výjimek pro vstupy a vjezdy vlastníků pozemků, uživatele pozemků, pracovníky různých služeb, zásobování, zdravotní péče apod. by znamenalo nepřiměřené a nadbytečné administrativní zatížení vodoprávních úřadů.

Je proto logické ponechání v kompetenci př́ílušného vodoprávního úřadu při stanovení nebo změně ochranného pásma, i vymezení okruhu osob, které smí do ochranného pásma l. stupně vstupovat a za jakých podmínek.

„Do ochranného pásma l. stupně je zakázán vstup a vjezd, nestanoví-li vodoprávní úrad rozhodnutím nebo opatřením obecné povahy jinak nebo nebylo-li jinak stanoveno podle předchozích predpisů prì stanovení ochranných pásem vodního zdroje." 


\section{NÁHRADY ZA OMEZENÍ UŽíVÁNÍ}

\section{NEMOVITOSTÍ V OPVZ - § 30 ODST. 11}

Náhrady za omezení užívání zemědělských pozemků vlastníkům zemědělských pozemků jsou prakticky rovněž problematické. Vzhledem ke skutečnosti, že na většině zemědělské půdy v České republice nehospodaří její vlastníci ale uživatelé (nájemci, pachtýři), je otázkou, kdo z těchto subjektů by měl být přijemcem této náhrady.

Naprostá většina zemědělských pozemků je pronajata na základě dlouhodobých nájemních smluv, jejichž změna je problematická, a to převážně pro odpor uživatelů zemědělských pozemků. Je proto velmi komplikované, jestliže náhradu za omezení užívání zemědělských pozemků mohou získat jen jejich vlastníci. Prakticky to proto funguje tak, že náhrady za omezení jejich užívání inkasují jejich nájemci, na základě plných mocí od vlastníka, pokud mezi nimi dojde k dohodě.

Prakticky by tedy byly v OPVZ vypláceny dvě různé náhrady - vlastníkům pozemků např. za změnu druhu pozemku (např. orná půda na trvalý travní porost) a dále nájemcům zemědělských pozemků za omezení zemědělského obhospodařování.

„Za prokázané omezení vlastnictví pozemků a staveb v ochranných pásmech vodních zdrojů náleží vlastníkưm těchto pozemků a staveb náhrada, kterou jsou povinni na jejich žádost poskytnout $v$ prípadě vodárenských nádrži vlastníci vodních dël umožnujicích $v$ nich vzdouvání vody, v ostatních prípadech oprávnění k odběru vody z vodního zdroje; je-li jich více, poměrně podle povoleného množství odebírané vody. Nedojde-li o poskytnutí náhrady k dohodě, rozhodne o jednorázové náhradě soud. Náhrada za omezení obhospodařování zemědělských pozemků náleží jejich uživatelům (nájemcům, pachtýřum) podle zvláštního predpisu."

Princip stávající právní úpravy je však jiný. Náhrady mají být vypláceny pouze vlastníkům pozemků a vztah mezi vlastníkem a nájemcem má být řešen v nájemní nebo pachtovní smlouvě, kde by prípadné řešení náhrad za omezení obhospodařování zemědělských pozemků měly být mezi vlastníkem a nájemcem jasně definovány a popsány.

\section{PŘECHODNÁ USTANOVENÍ}

Za účelem řešení nevyhovujícího stavu OPVZ je vhodné také upravit přechodná ustanovení vodního zákona.

$\checkmark$ minulosti bylo stanoveno velké množství pásem hygienické ochrany a OPVZ rozhodnutím příslušných správních orgánů. Jimi uložená omezení jsou stále platná. Vzhledem k tomu, že správní rozhodnutí o stanovení OPVZ bylo závazné jen pro účastníky těchto řízení, bylo by jejich vymáhání problematické u vlastníků nemovitostí, kteří nebyli účastníky pưvodního řízení o stanovení OPVZ. Je proto otázkou, zda by bylo možné stanovit, že vymezení těchto ochranných pásem je závazné včetně obecných omezení užívání nemovitostí v nich včetně zákazů vstupu, omezení zemědělského obhospodařování pozemků, hospodaření v lesích atd. i pro právní nástupce původních vlastníků.

Druhá změna $v$ prechodných ustanoveních by měla souviset s celkovou evidencí OPVZ (včetně PHO) na MŽP ČR a jejich záznamem v katastru nemovitostí.

Z hlediska veřejného zájmu je zcela žádoucí, aby byla v katastru nemovitostí vedena všechna OPVZ přinejmenším pro obecnou informaci související s možností využití pozemků a nemovitostí v těchto ochranných pásmech pro prípadné zájemce o koupi nebo užívání konkrétních nemovitostí.

Zároveň je vhodné, aby ta ochranná pásma stanovená v minulosti, u nichž již není využíván zdroj a není využitelným vodním zdrojem, a tudíz již nejsou nutná, zanikla samovolně $v$ prípadě, že vlastník souvisejícího vodního díla neprokáže potřebnou aktivitu.

„Subjekty, které mají právo vodu z vodního zdroje odebírat, prípadněti, kteřio takové povolení žádají, u vodárenských nádrží pak ti, kteří vlastní vodní díla sloužící ke vzdouvání vodní hladiny, jsou povinni nejpozději do ................ prèedložit př̌islušnému katastrálnímu úradu potřebné doklady pro vyznačení stanovených ochranných pásem stávajicích vodnich zdrojů dosud v katastru nemovitostínevyznačených. Stanovená ochranná pásma v katastru nemovitostí po tomto datu nevyznačená se považuji za zrušená."

\section{ZÁKLADNÍ RÁMEC NOVÉ VYHLÁŠKY NAHRAZUIÍCI VYHLÁŠKU Č. 137/1999 SB., KTEROU SE STANOVÍ SEZNAM VODÁRENSKÝCH NÁDRŽÍ A ZÁSADY PRO STANOVENÍ A ZMĚNY OCHRANNÝCH PÁSEM VODNÍCH ZDROJŮ}

Návrh vyhlášky vychází ze současných znalostí a postojů k problematice, zároveň jsou zohledněny určité zvyklosti, které jsou již v procesu stanovení a změn OPVZ obecně zažité. Vyhláška je rozdělena na dvě části, přičemž část první se týká Zásad pro stanovení a změny ochranných pásem vodních zdrojůu část druhá pak obsahuje Seznam vodárenských nádrží. Zde je určitá změna také v tom, že název vyhlášky je nejprve zaměřen na jeho podstatnější část (OPVZ), následně na seznam nádrží - vyhláška Ministerstva životního prostředí, kterou se stanoví zásady pro stanovení a změny ochranných pásem vodních zdrojů a seznam vodárenských nádrží.

Část první by bylo vhodné rozdělit do tří paragrafư. V prvním by měla být řešena potřeba individuality každého takového procesu.

\section{$\S 1$}

1. Ochranná pásma vodních zdrojů se stanovují na základě odborného posouzení stavu území a potřeb ochrany vydatnosti, jakosti a zdravotní nezávadnosti vodního zdroje ve vztahu $k$ jeho hydrologickému nebo hydrogeologickému povodí.

2. Ochranná pásma vodních zdrojů se navrhuji individuálním postupem s prìhlédnutím k zásadám pro stanovení a změny ochranných pásem vodních zdrojů uvedených v této vyhlášce.

Druhý paragraf by měl být rámcovým přehledem všech potřebných a relevantních podkladů, které je zapotřebí préedložit při stanovení či změnách OPVZ.

\section{$\S 2$}

1. Podklady pro stanovení či změnu ochranných pásem zahrnují zejména:

a) Popisné a technické údaje o vodním zdroji a odběru vody, jako jsou zejména zpưsob jímáni, odběru, vodoprávní dokumentace, předpokládané podmínky zásobování pitnou vodou.

b) Prírodnípodmínky a charakteristika územízahrnujícígeomorfologické, hydrologické, klimatické podmínky, pedologické, geologické, hydrogeologické podminky, ochranná pásma a ochranná území jiných zájmů podle zvláštních predpisů, územni plán, projekt technického rešení.

c) Provozní podklady, výsledek terénního šetření a dalši relevantní podklady.

d) Analýzu rizik ohroženi vydatnosti, jakosti nebo zdravotní nezávadnosti, která obsahuje analýzu jakosti vody, prognózu dalšiho vývoje, ohrožení vodního zdroje vlivem prírodních poměrü, odběry vody, nakládáni s vodami, nakládáníse závadnými látkami, charakteristiku zástavby a hospodářského využivání území, údaje o bodových, plošných, difúznich zdrojích znečištění a činnostech, které mohou ohrozit vydatnost, jakost nebo zdravotní nezávadnost vodního zdroje a závěr analýzy rizik sodpovídajícím zdůvodněním. 
e) Návrh rozsahu ochranného pásma a jeho zdůvodnění s uvedením jímacích (odběrných) objektů, které jsou předmětem dokumentace, vymezení rozsahu ochranného pásma I. stupně, vymezení rozsahu ochranného pásma II. stupně, návrh ochranných opatření v ochranných pásmech, prikkázaný režim činností v ochranném pásmu, pokud to mistní podminky vyžadují a závěrečné zhodnocení návrhu ochranných pásem a zdưvodnění ochranných opatření.

$\checkmark$ třetím paragrafu by měly být stanoveny zásady, které jsou obecně už zažité, a to jak z pohledu zákonodárců, tak z pohledu veřejnosti. Zaměřen je na značení hranice OPVZ.

\section{$\S 3$}

1. Hranice ochranných pásem se vyznačují na viditelných mistech tabulemi s nápisem "ochranné pásmo I/II. stupně vodního zdroje". V prípadě ochranného pásma I. stupně, kde je ze zákona stanoven zákaz vstupu a vjezdu, se doplní na tabuli nápis "Nepovolaným vstup zakázán".

2. Ochranné pásmo II. stupně se v terénu označuje obvykle pouze $v$ mistech se zvýšeným nebezpečím ohrožení nebo znečištěni vodniho zdroje a $v$ mistech krížení hranice ochranného pásma s komunikacemi. Probíhá-li hranice ochranného pásma vodní hladinou nádrže, umístí se tabule na plovoucí zakotvenébóje.

Dále k navržené vyhlášce patří príloha stanovující seznam vodárenských nádrží, kterých je evidováno 47 . Zde by oproti původní vyhlášce nemuselo dojít k žádné změně.

V této podobě by nová vyhláška byla kompaktní se současným zněním platného (resp. novelizovaného) vodního zákona a systematicky by doplnila přehled všech pravidel a požadavků při stanovení či změně OPVZ.

\section{METODIKY A METODICKÉ POSTUPY}

V roce 2012 byly pro Ministerstvo životního prostředí ČR zpracovány metodiky, které měly pomoci při stanovování a řešení změn OPVZ.

Cílem metodik je sjednocení pracovního postupu zpracování dokumentací OPVZ povrchových vod v celém rozsahu povodí povrchových vodních zdrojů a OPVZ podzemních vod.

Předmětem metodiky je tzv. speciální ochrana vodních zdrojů vycházející důsledně z požadavků ustanovení § 30 vodního zákona a nově navržené vyhlášky, kterou se stanoví zásady pro stanovení a změny ochranných pásem vodních zdrojů a seznam vodárenských nádrží.

Metodiky přesto nemohou postihnout všechny budoucí požadavky př́slušných vodoprávních úřadů, které mohou být vzneseny k předložené dokumentaci v průběhu projednávání návrhu na stanovení OPVZ. Přesto však odpovídají současnému trendu a snahám o novelizaci legislativního prostředí v oblasti OPVZ. Podrobný rozbor metodik a zpracovaných podkladů však není možno z hlediska daného rozsahu př́spěvku provést.

\section{PROJEKT „AKTUALIZACE OCHRANNÝCH PÁSEM VODNÍCH ZDROJÜ“- SOUČASNÝ STAV, VÝSLEDKY}

Oddělení GIS a kartografie VúV TGM, v. v. i., řeší v letech 2015-2017 projekt podpory výkonu státní správy Ministerstva životního prostředí ČR s názvem Aktualizace ochranných pásem vodních zdrojů a ochranných pásem vodárenských nádrží (dále také OPVN).

Cílem projektu je vytvořit prostorovou vrstvu správně zakreslených ochranných pásem vodních zdrojů s ověřenou platností a s připojeným vodoprávním rozhodnutím (resp. opatřením obecné povahy) v digitální podobě. $\vee$ průběhu řešení byla navázána spolupráce se všemi krajskými úřady $\vee$ ČR. Protože situace $v$ evidenci pásem je $v$ rámci jednotlivých krajů velmi odlišná, je nutné řešit získání a implementaci ověřených dat individuálně. V řadě případů je nezbytné oslovit vodoprávní úřady obcí s rozšiřenou působností (VÚ ORP). Značnou část pásem je nezbytné editovat ručně - pročíst príslušný dokument, opsat z něj

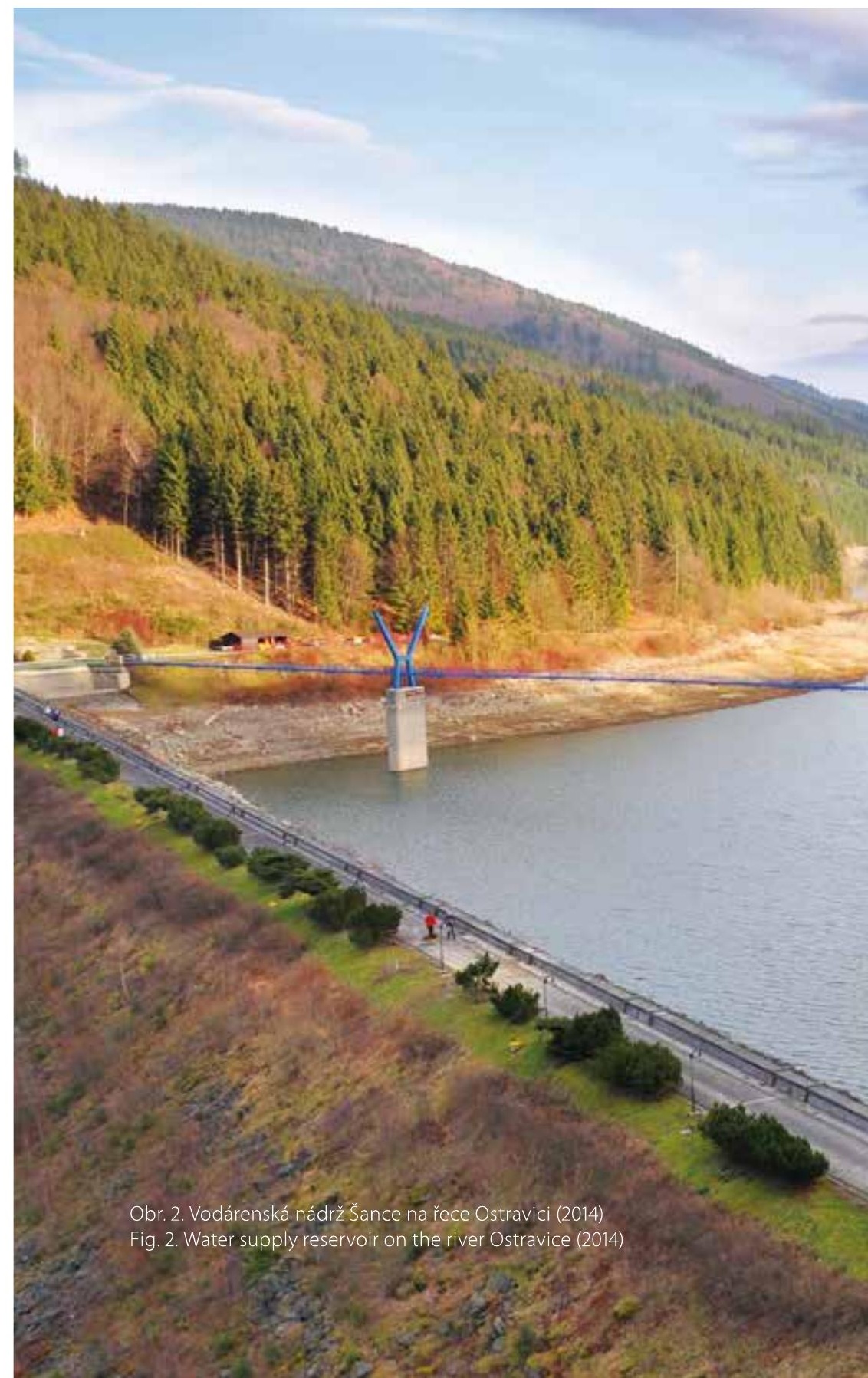




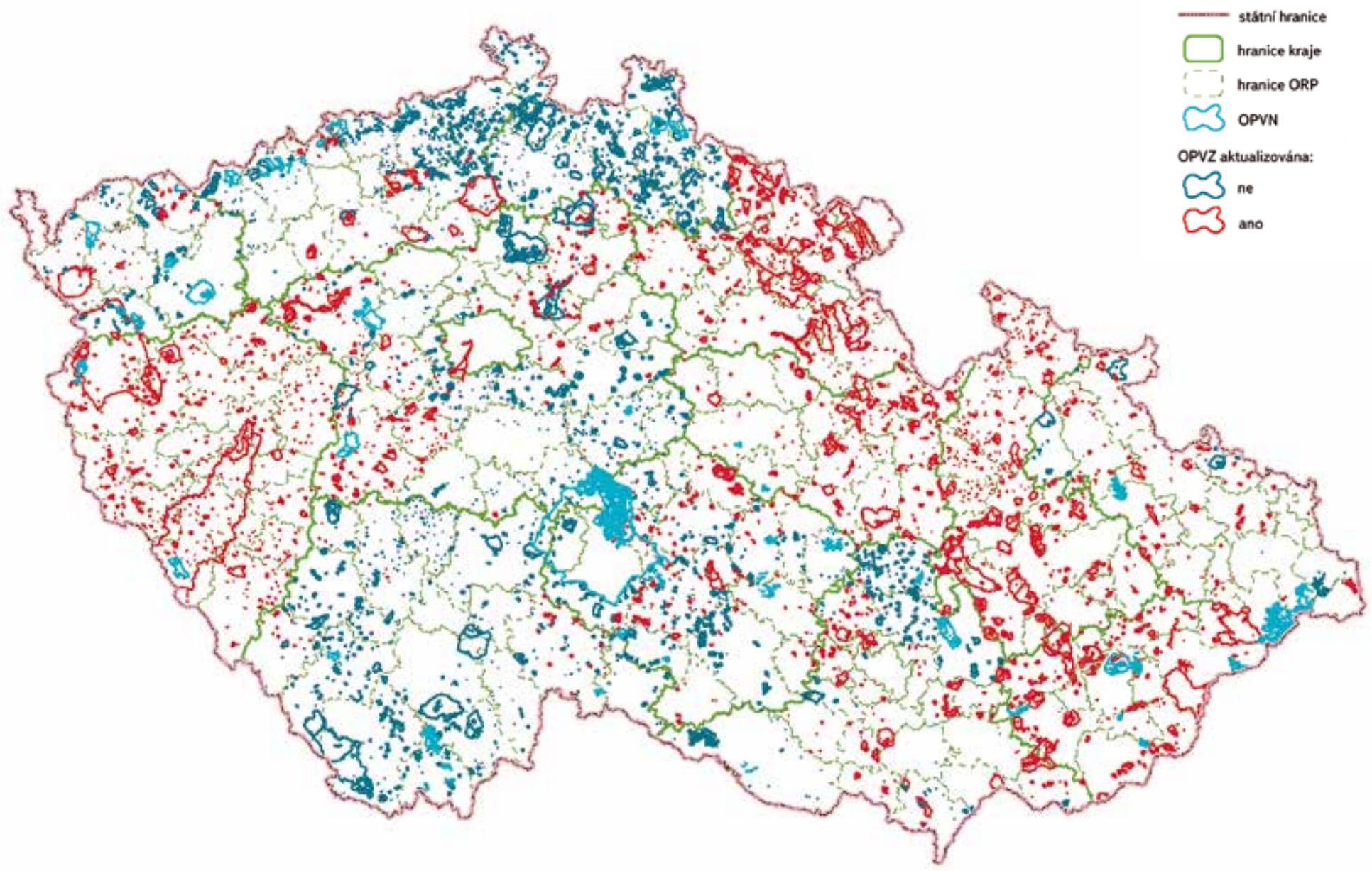

Obr. 3. Přehled stavu aktualizace ochranných pásem vodních zdrojů a ochranných pásem vodních nádrží k 15. březnu 2017

Fig. 3. Overview update status of water resources protection zones and buffer zones of water supply reservoirs on March 15,2017

V neposlední řadě práce komplikuje neochota některých Vú ke spolupráci, at' již z důvodu nedostatečné kapacity, či frustrace z opakovaných požadavků různých subjektů na zasílání podkladů.

Samotná aktualizace OPVZ a OPVN je výsledkem několika činností. V případě datových sad z krajských úřadů jsou po více či méně náročné úpravě dat převzaty zákresy pásem a dokumenty vodoprávních rozhodnutí. U podkladů z Vú ORP jsou jednotlivá pásma editována ručně. Polygony hranic pásem jsou opraveny podle zaslaných zákresů, atributová tabulka doplněna o informace z vodoprávních rozhodnutí a digitální podoba dokumentu je vložena do databáze.

V prvním čtvrtletí roku 2017 byla dokončena aktualizace OPVZ ze 4 celých krajů a 49 ORP (obr. 3). Celkem se jedná približně o $60 \%$ ověřených polygonů pásem. Aktualizace vrstvy OPVN započala teprve na konci roku 2016 opravou prvních několika pásem. Další verze aktualizace bude připravená k odevzdání v červnu 2017. Do konce listopadu 2017 podle požadavku MŽP ČR musí být projekt dokončen.

Aktualizace OPVZ a OPVN tak, jak byla definována v předmětu projektu, je časově omezená činnost. Cílem má být vytvoření aktuální geodatabáze platných pásem, a to pouze těch, ke kterým je připojena digitální forma vodoprávních rozhodnutí. Pásma, ke kterým nebylo možné dohledat príslušné dokumenty, budou z databáze vyřazena bez ohledu na jejich platnost. Protože ale agenda ochrany vodních zdrojů probíhá kontinuálně, nová pásma jsou vyhlašována, stará měněna či rušena, je nezbytné s aktualizací pásem pokračovat. Tým řešitelů navrhl praktický způsob, jak databázi udržet aktuální. Postup využije zákonem danou povinnost vodoprávních úradů evidovat veškerou dokumentaci týkající se (mimo jiné) OPVZ a OPVN ve vodoprávní evidenci. Zákresy nově vyhlašovaných pásem musí rovněž hlásit katastrálnímu úřadu. Tento postup vyžaduje spolupráci MŽP ČR ve věci finančního krytí a také kontroly a motivace VU ORP k vyplňování vodoprávní evidence. A také dohodu s ČúZK s cílem najít cestu, jak získat prostorová data ochranných pásem z katastru nemovitostí s výhledem na pravidelnou aktualizaci vrstvy OPVZ a OPVN.

Vrstva OPVZ a OPVN je součástí (podkladovou vrstvou) systému Veřejného registru půdy (LPIS), který spravuje MZE ČR a podle kterého Ústřední kontrolní a zkušební ústav zemědělský kontroluje činnost zemědělských podniků. Chyba v zákresu pásma může ovlivnit způsob obhospodařování konkrétního půdního bloku, udělení pokut a dotační politiku. Je nezbytné prodiskutovat budoucí spolupráci MŽP a MZe ČR v této oblasti a zajistit pravidelnou a koncepční údržbu databáze. 


\section{Převymezení OPVZ}

Ačkoliv by se našla celá řada objektivních důvodů k přehodnocení některých současných OPVZ a k jejich následnému převymezení, samotný proces je do značné míry dosti komplikovaný. Zkušenosti subjektů, které přehodnocování OPVZ provádějí, upozorňuji zejména na významnou časovou a personální zátěž během celého postupu, který v prípadě rozsáhlejších OPVZ může trvat i několik let. Dalším podstatným faktem je náročnost ekonomická, kterou správci povodí a vodohospodářské subjekty musí řešit za svých zdrojü. Pokud by proces převymezení OPVZ byl požadován legislativou, je nutné, aby se následně stát také podílel na jeho podpoře dotační formou ze zdrojů operačních programů a podobných opatření.

\section{ZÁVĚR}

Není v omezených kapacitních možnostech príspěvku probrat všechna současná úskalí, která se týkají ochranných pásem vodních zdrojů na našem území V článku uvedené informace jsou názorem jeho autorů a je nepochybně zřejmé, že názorová základna k problematice bude mnohem širší a různorodá. Přesto by se výše uvedené pojednání mohlo stát jedním z iniciátorů mezioborové diskuse a konečnému vyřešení současného nevyhovujícího stavu.

Jak vyplývá z výše provedené analýzy, máme dnes poněkud nesourodé právní normy, kdy klíčová vyhláška č. 137/1999 Sb., kterou se stanoví seznam vodárenských nádrží a zásady pro stanovení a změny ochranných pásem vodních zdrojů, jako prováděcí prèedpis k $§ 30$ zákona č. 254/2001 Sb., tomuto zákonu chronologicky předcházela a v současné době je nevyhovující. Navíc po zrušení směrnice Ministerstva zdravotnictví č. 51/1079 není momentálně k dispozici žádný centrální podrobnější metodický nástroj ke stanovování OPVZ.

Ačkoliv se odborná veřejnost problematikou již dlouhé roky zabývá [7-9], kompetentní orgány problém OPVZ neřeší.

Subjekty, kterých se oblast práce s vymezováním, změnami a rušením OPVZ prímo dotýká, mají většinou zpracovány své interní postupy a metodiky, které jsou v maximální možné miře $v$ souladu se současným legislativním prostředím a obecnými zvyklostmi. Prístup těchto institucí je zodpovědný, na druhou stranu však může být absence potřebných nástrojů potencionálním prostorem pro porušování zákonných předpisů, at již z neznalosti a neinformovanosti, či s určitým záměrem.

Predložený návrh novelizace a úprav legislativních prostředků by měl být prvotním impulsem k další systematické činnosti v oblasti - provedení novelizací všech relevantních zákonných předpisů, následné sjednocení metodických postupů a systematické evidence OPVZ. Momentálně řešený projekt Aktualizace ochranných pásem vodních zdrojů by mohl být zásadním stavebním prvkem celého systému evidence všech platných ochranných pásem vodních zdrojů na území České republiky.

\section{Literatura}

[1] Vyhláška č. 137/1999 Sb., kterou se stanoví seznam vodárenských nádrží a zásady pro stanovení a změny ochranných pásem.

[2] Zákon č. 254/2001 Sb., o vodách (vodní zákon), v platném znění.

[3] NOVÁK, J. Ochrana vod (interní materiál). Brno: Vodárenská akciová společnost, a. s., 2010.

[4] HORÁČEK, Z. Proces vydávání opatření obecné povahy vodoprávními úřady. Vodní hospodářství, 2012, roč. 62, č. 11. s. 373-376.

[5] STRNAD, Z. Opatření obecné povahy (nejen) podle vodního zákona, Vodni hospodářství, 2012, roč. 62 č. 6, s. 230-235.
[6] Tvorba metodik pro vymezování ochranných pásem vodních zdrojů, závěrečná zpráva, Výzkumný ústav meliorací a ochrany půdy, v.v. i., Praha, únor 2012. Metodika pro zpracování dokumentace ochranných pásem povrchových vodních zdrojů, Výzkumný ústav meliorací a ochrany půdy, v.vi.i., Povodí VItavy, státní podnik, Praha, únor 2012. Katalog opatření OPVZ, Výzkumný ústav melioraci a ochrany půdy, v.vi.i., Povodí VItavy, státní podnik, Praha, únor 2012. Ideový návrh směrnice pro stanovení ochranných pásem vodních zdrojů podzemní vody, Výzkumný ústav meliorací a ochrany půdy, v.v.i., Povodí Vltavy, státní podnik, Praha, únor 2012. Metodické doporučení k § 2, odstavec 3 a 4 , vyhlášky č. 137/1999 Sb. po její navrhované změně, Výzkumný ústav meliorací a ochrany půdy, v.v.i.. Povodí Vltavy, státní podnik, Praha, únor 2012

[7] NOVÁK, J. a OPPELTOVÁ, P. Stanovení ochranných pásem vodních zdrojů po novele vodního zákona poznatky z praxe, zpracování návrhů OP, vliv na účinnost OP. Sborník konference Pitná voda 2012, České Budějovice, 2012, s. 297-302.

[8] NOVÁK, J. a OPPETLOVÁ P. Optimalizace ochranných pásem vodního zdroje Vranov ve smyslu platných právnich predpisů a praktických zkušeností. Sborník konference Pitná voda 2014, České Budějovice, 2014, s. $93-98$.

[9] Odborný seminář Ochranná pásma povrchových zdrojů pitné vody, Praha, 2016.

\section{Autoři}

Ing. Robert Kořínek, Ph.D.'

凶robert.korinek@vuv.cz

Ing. Hana Nováková, Ph.D.'

凶hana.novakova@vuv.cz

Jaroslava Nietscheová, prom. práv. ${ }^{2}$

凶nietscheova@pvl.cz

${ }^{1}$ Výzkumný ústav vodohospodářský T. G. Masaryka, v. v. i.

${ }^{2}$ Povodí Vltavy, s. p.

Příspěvek prošel lektorským řizením.

\section{ACTUAL SITUATION OF THE PROTECTION ZONES OF WATER RESOURCES PROBLEMS}

\section{KORINEK, R.'; NOVAKOVA, H.; NIETSCHEOVA, J. ${ }^{2}$}

'TGM Water Research Institute, p. r. i.

${ }^{2}$ Povodí Vltavy, State Enterprise

Keywords: protection zone - water resource - surface water - ground water - legislation - water legislation

The current situation in the field of water resources protection zones in the Czech Republic is problematic for a long time, not only in terms of their definition, but also the correct setting measures or data availability to the public. Protection zones are bounded by the Czech Republic for more than 50 years, and many of them are still in force, despite the objective reasons for the change.

In terms of legal instruments defining water resources protection zones moves at unstable environment. First, apply here Decree no. 137/1999 Coll., setting the list of water supply reservoirs and principles for the establishment and modification of protection zones of water sources. Second, the definition of water resources protection zones is conforming to $\S 30$ of Act no. 254/2001 Coll., on waters. This may produce different attitudes to the whole issue. 